\title{
STUDY OF ISLAMIC MONETARY POLICY LITERATURE: (Effectiveness of Real Sector Performance Strengthening)
}

\author{
Andri Soemitra ${ }^{1}$ Rifki Ismal ${ }^{2}$ Abi Waqqosh ${ }^{3}$ Heny Liya Hasibuan ${ }^{4}$ dan Husni Pasarela ${ }^{5}$ \\ 1,4,5 North Sumatera State Islamic University \\ ${ }^{2}$ Sekolah Tinggi Ilmu Ekonomi Islam Tazkia Bogor \\ ${ }^{3}$ Sekolah Tinggi Agama Islam Swasta Al-Islahiyah Binjai \\ ${ }^{6}$ Politeknik Negeri Lhokseumawe \\ Email Correspondent : abipaytren@gmail.com, henyliyahasibuan@gmail.com, haris@pnl.ac.id
}

\begin{abstract}
The purpose of this article is to analyze how effective the Islamic monetary policy system is in maintaining or improving the performance of the real sector. And how Islamic monetary economic policy is able to maintain stability between the real sector and the monetary sector compared to the implementation of conventional monetary economic policy. The research design uses library research design (library study design). namely a research by studying, researching and reviewing relevant library materials. The data collection method used in this study is documentation, namely the method of data collection by reviewing various books (literature) that are relevant to the subject matter to be studied. With data analysis techniques using content analysis techniques, (Content Analysis) is research that is in-depth discussion of the contents of a written or printed information in the mass media. Which in the analysis it was found that Islamic monetary policy is effective in improving the performance of the real sector.
\end{abstract}

Keywords : Islamic Monetary Policy, Monetary Sector, Real Sector.

\section{PRELIMINARY}


If we look at the development of the world economy, the biggest potential for developing countries' national income is from the real sector. Including Indonesia, the real sector is one of the most important variables for its economy. The real sector is the largest absorber of labor for the community, because the real economic sector involves the middle and lower class economic communities directly. But unfortunately, because of the large capacity to absorb labor, it often becomes a boomerang when experiencing economic shocks, because the community will get the impact directly. And often the problem is that the real sector growth tends to be slower than the monetary sector.

In an ideal economic analysis, the economy is said to be good if it has a balance between the real sector and the monetary sector. The two influence each other in the continuity of the economic cycle. The monetary sector is an important network and affects the real economic sector. So monetary policy is an important instrument of policy in the modern economic system. This also applies in the Islamic economic system, but the difference lies in the purpose and prohibition of interest in Islam.(Muhammad, n.d.)

In the conventional economy, the transmission line of policy is through six channels, namely money, credit, interest rates, exchange rates, asset prices and expectations. However, the six transmission lines in conventional monetary policy are not used in sharia monetary policy transmission. The main difference is that the rate line cannot be used in Islamic monetary transmission because the concept of interest is prohibited in Islamic teachings.(Ascarya, 2009). If in conventional monetary policy instruments it is known as SBI and PUAB, but in sharia it is known as Sharia SBI (SBIS) and sharia PUA (PUAS). SBIS uses a sales contract, however, SBIS can be issued by BI with musyarakah, mudharabah, wadiah, qord and wakalah contracts. Meanwhile, PUAS consists of Interbank Musharakah Investment (SIMA) and Commodity Trading Certificate Based on Sharia Principles (SIKA).

However, in its application, conventional monetary economic policies often have a negative impact, the interest rate policy that is carried out causes credit stiffness due to the high credit repayment burden while the expected profit from the business cycle decreases. As a result, Indonesia's production and exports decreased, resulting in a decrease in national income. 
In contrast to conventional, Islamivarious economic problems in monetary economics prohibits currency tradingdonesia. Because Indonesia is an because money is a medium of exchange fbslamic country whose values can be production activities and disrupts economidhered to in moderation and balance because output production cannot keadjustments to the problem.

pace with the speed of the monetary sector.(Karim, 2013) Islamic economics LITERATURE REVIEW prohibits usury because it causes the circulatidn Islamic Monetary Policy of money to be higher than the productivity of Monetary policy is state politics in producing goods (buble economy) and madetermining regulations and actions in people miserable. Therefore, Islamic econorthiesstate finances.(NabhanI, 1996). More uses the principle of profit sharing in investnspacifically, monetary policy means the activities because profit sharing will incresernment's macro action through the business productivity (Islamic time valuecenfral bank by influencing the creation money), balance the real and monetary secofirnoney. By influencing the creation of because the business must exist / use ntlomey, the government can influence partnership principle so that if there is profthte/money supply, which is why the loss it is shared. government can influence investment

Seeing from the description of the problem above, this paper aims to analyze how effective the Islamic monetary policy system is in maintaining or improving the performance of the real sector. And how Islamic monetary economic policy is able to maintain stability between the real sector and the monetary sector compared to the implementation of conventional monetary economic policy. Because it is not impossible if the Islamic monetary policy system as an alternative solution in dealing with spending, influence aggregate demand and the price level in order to create the desired economic conditions.(Budiono, 2001)

Islamic monetary policy adheres to the basic principles of Islamic economics, namely:

(a) The supreme power belongs to Allah and only Allah is the absolute owner.

(b) Humans are caliphs (leaders) on earth, but are not the real owners. 
(c) All that is owned by humans is because of Allah's permission, therefore the less fortunate brothers have rights to the wealth of the more fortunate brothers.

(d) Wealth may not be piled up or stockpiled.

(e) Wealth must be rotated.

(f) Removing the gap between individuals in the economy, can eliminate conflicts between groups

(g) Establish that obligations are mandatory and voluntary for all individuals, including for poor members of society.(Karim, 2001)

In its application, Islamic monetary policy must be free from elements of usury and bank interest. In Islam, usury, including bank interest, is strictly prohibited. With this prohibition, bank interest which in a capitalist economy is the main instrument of monetary management is no longer valid. Monetary management in Islam is good based on the principle of profit sharing.

\section{a. Objectives of Islamic Monetary}

\section{Policy}

A policy is declared functioning if the system can achieve the objectives of the policy. In Islamic monetary economic policy the objectives to be achieved are:

1. Economic Prosperity With Full Job Opportunities

This goal is closely related to maqasid shar'iyah. Economic welfare takes the form of the fulfillment of all basic human needs, the elimination of all major sources of difficulty and an increase in the quality of life morally and materially. Also the creation of an economic environment where the caliph of Allah is able to use his time, physical and mental abilities for the enrichment of himself, his family and society. Welfare is not maximizing wealth and consumption for oneself regardless of others, or for certain groups and ignoring other groups. Humans live in the world as vicegerents of Allah with other humans who are also vicegerents of Allah. The available resources are for all human beings. Therefore, the use of resources by individuals is legal, but limited so as not to jeopardize social happiness and good. It even brings good to the social environment.

Utilization of resources must take into account Islamic values which include (a) Material prosperity should not be achieved through the production 
of goods and services that are not essential and are morally questionable. (b) Should not widen the social gap between the rich and the poor. (c) Must not cause harm to current or future generations by damaging the physical and moral environment.

2. Socio-Economic Justice and Distribution of Income and Wealth

Justice is putting things in their proper place. This concept contains two elements of understanding. (a) a form of balance and comparison between persons who have rights. (b) The rights of a person should be given and assigned carefully.

However, justice is not a generalization in the distribution of wealth. This is because each individual has differences that allow the acquisition of wealth. Nor is it themaximum control of wealth and maintaining wealth for oneself as a reflection of the rightto work. This justice reflects that material rewards must be given fairly for the hard work of creativity and its contribution to the output. Wealth is indeed the result of individual efforts, but in that wealth there are other people's rights. Wealth must thus be distributed to those who have rights. Related to this goal, the regulation of the central bank must be realistic and reduce the concentration of wealth and power in the hands of a few people.

\section{Value for Money Stability}

The stability of the value of money has a major influence on economic life, both ideologically and practically, because money determines the value and price of goods and services.(Saud, 1996) The uncertainty of money causes damage to the economy, because the economic order is based on the principle of supply before demand, so forecasting a price accurately becomes difficult.

The uncertainty of the value of money, which is more in the form of inflation than deflation, shows that money cannot function as a unit of account that is just and correct, and causes economic actors to act unfairly to other actors without realizing it, by degrading monetary assets without their knowledge. . Inflation exacerbates a climate of uncertainty in which economic decisions are made, raises concerns about capital formation and leads to misallocation of resources. And it even tends to damage moral values because it gives rewards to speculative efforts which ultimately inflict losses on 
productive activities and exacerbate income inequality.

The stability of the value of money is a top priority in Islamic monetary management activities. The stability of the value of money reflected in the stability of the price level greatly influences the realization of the achievement of a country's economic development goals, such as; fulfillment of basic needs, equitable distribution of income and wealth, optimum real economic growth rate, expansion of employment opportunities and overall economic stability.

\section{b. Islamic Monetary Policy Strategy}

Practically in Islamic monetary management it is not allowed to use interest rates, because as the basis of the Islamic economic system that usury is haram, while interest rates are usury. Therefore, the Islamic monetary strategy must abandon interest rates. Therationale of Islamic monetary management is the creation of stability in the demand for money and directing the demand for money to important and productive goals, so that any instrument that will lead to instability and the allocation of unproductive sources of funds will be abandoned. In other words, the circulation of money is attempted to be allocated to the real productive sector, therefore in Islam there is no demand for money for speculation as is known in Keynes' theory which classifies the demand for money into three motives, motives for transactions, precaution and speculation. The Islamic monetary strategy is the elimination of interest rates and the obligation to pay taxes on productive costs that are unemployed, so that it will eliminate people's initiative to hold idle money so as to encourage people to do: a) Qard (lending wealth to others). (b) Muajjal Sales. (c) Muḍ̄ārabah.(Karim, 2013)

The owners of the funds will invest their funds in activities that provide the largest actual return, so the higher the demand for money for investment in the real sector or theneed for a greater supply of funds for investment, the level of expected profit that will begiven will be relatively decreased. Because the actual rate of return does not fluctuate like interest rates, it will make the demand for money more stable.

\section{c.Islamic Monetary Policy Instruments}

As mentioned above, Islamic monetary policy is different from 
conventional monetary policy. Instruments of Islamic monetary policy are grouped into two major groups, namely: (1) Quantitative Control in the distribution of funds and (2) Methods that can ensure that the allocation of financing runs well in useful and productive sectors.

Quantitative control of lending can be in the form of; First, the Statutory reserve requirement is that this instrument in Islamic economics is an important instrument because the discount rate and open market operations cannot apply. Commercial banks are required to place a portion of their funds originating from demand deposits at the central bank as a statutory reverse. This reserve requirement only applies to demand deposits, not to mudarobah deposits, because mudarobah deposits are the equity of savers in the bank that has the possibility of profit and risk of loss. This system will work well if it is supported by good bank supervision.(Muhammad, 2002)

Second, Credit Ceiling is the highest credit limit that can be given by commercialbanks to ensure that the total credit creation is in accordance with the monetary target. By only relying on reserve requirements that make it easier for the central bank to make adjustments to High Powered Money, it does not guarantee the success of monetary management, because credit expansion can occur beyond the targeted amount. This happens because the flow of funds that can be accurately estimated into the banking system only comes from the exchange of the central bank with commercial banks, while the flow of funds from other sources that enter the banking system is difficult to determine accurately. Another thing that also affects is the unclear relationship between the reserve requirements that exist in commercial banks and credit expansion. In short(Chapra, 2001)

Third, Demand Deposits. To influence reserves at commercial banks, the government is authorized to transfer the demand for government deposits at the central bank to and from commercial banks. This instrument has a function similar to the function of open market operations, where the central bank directly influences commercial banks.(Muhammad, 2002)

Fourth, Common Pool. Namely, an instrument that requires commercial banks toset aside a portion of the deposit 
they control in a certain proportion based on a mutual agreement in order to overcome liquidity problems. This instrument has a similar functionwith the rediscount facility at conventional central banks to solve liquidity problems.(Siregar, 2001)

Fifth, Moral Suasion. Namely personal contacts, consultations and central bank meetings with commercial banks to monitor the strengths and problems facing commercial banks. With this instrument, the central bank can clearly and precisely provide advice to overcome the problems faced by banks so that it will facilitate the achievement of the planned banking goals

Furthermore, methods that can ensure that credit allocation can take place well in useful and productive sectors include; First, Treating the Created Money as Fay'. The core money created by the central bank comes from exercising prerogatives. This brings benefits to the central bank because the costs incurred to create money are smaller than the nominal value or known as money seigniorage. Therefore, with this seignioraga, it is natural for the central bank to set aside some of its funds as fay or tax which is mainly used to finance projects that can improve the socio-economic conditions of the poor and can reduce inequality in the distribution of income and wealth. These funds should not be used by the government to finance projects that only benefit the rich. With this instrument, the allocation of funds can be accounted for for distribution to useful and productive activities

Second, Goal Oriented Allocation of Credit, namely the allocation of bank financing based on the purpose of utilization will provide optimum benefits for all business actors, will produce goods and services that can be distributed to all levels of society. In reality, this is difficult to happen because the funds that can be collected by general banks come mostly from small savers, but their use in the form of credit is morefocused on big entrepreneurs. The reluctance of banks to extend credit to small businessesis due to the higher risk and greater expenditure in financing small businesses. The consequence of this is that it is very difficult for small businesses to obtain financing from banks, even if banks are willing to provide funds for financing small businesses. but accompanied by various 
conditions that are difficult for them, especially guarantee requirements. Under these conditions, it can be estimated that the growth and survival of small businesses will be threatened even though small businesses have the potential to expand job opportunities. Generate production and can improve income distribution. To overcome this, it is necessary to have a guarantee scheme for banks in participating in financing productive businesses that do not violate Islamic values. Through this guarantee scheme, banks are not required to ask for guarantees from companies that apply for financing. In this case the bank faces challenges from the financing it does, namely the company being financed fails in business. If the failure is due to moral deviation, the bank will get the funds back,(Muhammad, 2002)

\section{Real Sector as a Potential}

\section{Commodity}

When we talk about the real sector, what we often hear and know is about imbalances and lags compared to the monetary sector. In fact, if it is understood, the real sector or what is commonly called the real sector is a sector that is in direct contact with economic activities in society that greatly influences or whose existence can be used as a benchmark to determine economic growth.

Problems that often occur in the real sector are often influenced by several factors, but the factors that often affect real sector problems stem from factors that affect investment in the real sector itself. As mentioned by Mia Angelina Setiawan, the main factors constraining investment in the real sector are First, policies in the industrial sector which are still weak and unfocused, such as: political stability and law enforcement, labor regulations, energy policies (fuel oil and electricity). , environmental policies, supervision of circulating goods and illegal imports, and so on that cause the domestic business climate to be unfavorable. Second, fiscal policy that is not comprehensive, because it is more focused on efforts to achieve temporary state revenue targets, whereas the long term (ie: industrial continuity) is unthinkable. Finally, monetary policy is still not in favor of the real sector because several sectors are considered high risk, such as: the banking intermediation function is not optimal, bank interest rates are high when compared to deposit rates, financial liquidity in financial institutions/banks 
for the industrial sector is very low. From the factors mentioned above, in the end, the competitiveness of real sector products is not competitive because they cannot meet market demands: competitive price, high quality, on time delivery and responsive toward trade communication. the banking intermediation function is not optimal, bank interest rates are high when compared to deposit rates, financial liquidity in financial institutions/banks for the industrial sector is very low. From the factors mentioned above, in the end, the competitiveness of real sector products is not competitive because they cannot meet market demands: competitive price, high quality, on time delivery and responsive toward trade communication. the banking intermediation function is not optimal, bank interest rates are high when compared to deposit rates, financial liquidity in financial institutions/banks for the industrial sector is very low. From the factors mentioned above, in the end, the competitiveness of real sector products is not competitive because they cannot meet market demands: competitive price, high quality, on time delivery and responsive toward trade communication.(Setiawan, 2015)
Whereas on the other hand, if the real sector is maximized, it should bring positive benefits and increase economic growth which in turn will bring prosperity to the community. Like the opinion of Irfan Syauqi who said that economic growth is very dependent on the real sector. In theory, the real sector is likened to a machine that can move the wheels of the economy.(Syauqi, 2016). This is because the real sector is a real sector, namely the sector that produces goods and services that exist in the community. If the real sector continues to increase significantly against a country, then the economic development in that country can be said to experience very good growth.

\section{RESEARCH METODOLOGY}

\section{Research Design}

This research uses library research design (library study design). namely a research by studying, researching and reviewing relevant library materials. Literature review serves to build concepts or theories that form the basis of studies in research.(Sujarweni, 2014). This is intended to describe Islamic Monetary Policy and Real Sector Performance related to the title that has been proposed in this study, as well as to 
answer the problems that have been formulated previously. then the approach used is:

(1) Descriptive approach, which is intended to provide an overview of the character's thoughts by outlining all the concepts/thoughts of the characters relevant to the research topic.

(2) Theoretical approach is an approach that seeks to study and process theories related to the topic of discussion.

2.Method of Collecting Data

Data collection methods are ways that can be used in data collection. The data collection method used in this research is documentation, namely the method of data collection by reviewing various books (literature) that are relevant to the subject matter to be studied(Arikuntoro, 2006)

\section{Technical Data Analysis}

To analyze the data that has been obtained, all data related and relevant to the topics discussed are collected from various sources and classified, then the data is described in detail, clearly and systematically so that in the end conclusions can be drawn from the topics discussed, then the author analyzes the data so that a conclusion is drawn. To obtain correct and precise results in analyzing the data, the authors use content analysis techniques. Content analysis is research that is an in-depth discussion of the content of written or printed information in the mass media. Content analysis can be used to analyze all forms of communication, be it newspapers, radio news, television advertisements and all other documentation materials.(Al., 2012)

\section{RESULT AND DISCUSSION}

From the description that has been done above, the results of the analysis show that Islamic monetary policy is more effective in improving the performance of the real sector, this is because:

FirstIn the Islamic monetary economic system there is no dichotomy between the real sector and the monetary sector. Because the monetary economy in Islam is a representation of the real sector. The monetary sector in the Islamic understanding is defined as the financing $\mathrm{method} / \mathrm{mechanism}$ of transactions in the real sector market. Therefore, the monetary sector and the real sector are interconnected. This is in accordance with the words of Allah in the Qur'an:

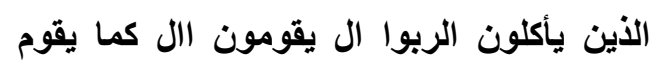

الأي يتخبطه الشيطن من المس ذلك بانهم قالوا انما 


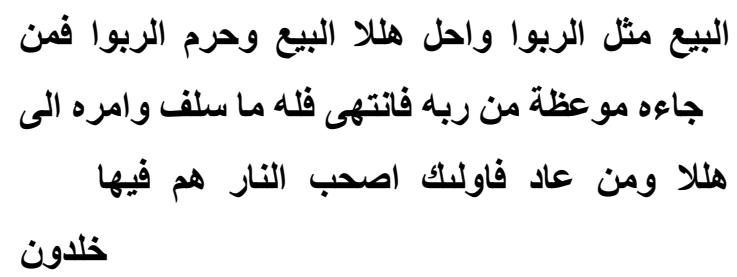

Meaning: Those who eat (transact with) usury cannot stand up, except like people who stagger because of the devil's trance. This happens because they say that buying and selling is the same as usury. In fact, Allah has permitted buying and selling and forbids usury. Whoever has come to him a warning from his Lord (regarding usury), then he stops so that what he has obtained before becomes his and his affairs (up to) to Allah. Whoever repeats (usury transactions), they are the inhabitants of hell. They stay in it.

From the verse it is illustrated that buying and selling transactions (trade) are things that are emphasized in Islamic economics.

Second,The basic principle of Islamic economics is that it does not use usury and bank interest in its transactions, while in conventional economics bank interest is used as an instrument for driving its economy. The advantages of Islamic monetary economic policy in this case are that it does not make it difficult for the community because the dominant bank interest rate is higher than the deposit interest, as a result for companies that manage goods and services as agents of the real sector it is difficult to develop their business. If Islamic monetary policy is carried out with this principle, the real sector in Indonesia will be guaranteed because MSMEs owned by the lower class people are easier to get capital and have no difficulty in returning it because of the absence of interest rates.

Third, Islamic monetary policy oriented to full employment. This policy will make the real sector more advanced, because human resources are more concerned. The welfare of the community is guaranteed because it has wide job opportunities and full employment opportunities.

Fourth, the existence of socioeconomic justice in Islamic monetary policy. This policy is implemented by regulating the central bank to be realistic and reducing the concentration of wealth and power in the hands of a few people so that the gap is not too far felt by the community. The impact, for the middle class and also the lower class can be guaranteed to jointly optimize existing resources for welfare.

Fifth, Stabilization of value for money. Poor stability in the value of money will result in concerns about the provision of capital and result in irregular 
allocation of resources. In fact, this tends to damage moral values because it rewards speculative efforts which ultimately inflict losses on productive activities and exacerbate income inequality. If people's income is not evenly distributed, as a result, the real sector will be disrupted, due to the inability of people's purchasing power. The result is inflation. However, if Islamic monetary policy is implemented, the stability of the value of money is maintained because it is an instrument of Islamic monetary policy.

However, the weakness of Islamic monetary policy is that there is still very little financing/capital available to the public. This should be the focus of the government, because Islamic monetary policy is very likely to be carried out as an alternative to the shortcomings of the conventional monetary policy system.

\section{CONCLUSION}

Monetary policy is a system of regulating money by the government in an economy in order to achieve human welfare. In Islamic values, monetary policy is carried out based on the basic principles of Islamic economics, namely: (a) The supreme power belongs to Allah and only Allah is the absolute owner. (b)
Humans are caliphs (leaders) on earth, but are not the real owners. (c) All that is owned by humans is because of Allah's permission, therefore the less fortunate brothers have rights to the wealth of the more fortunate brothers. (d) Wealth may not be piled up or stockpiled. (e) Wealth must be rotated. (f) Removing the gap between individuals in the economy, can eliminate conflicts between groups.

In Islamic economics, there is no dichotomy between the real sector and the monetary sector. The monetary sector is a result of financing transactions in the real market. The real sector and the monetary sector are interconnected.

With the above discussion, it can be concluded that Islamic monetary policy is effective in improving the performance of the real sector. Because the instruments of Islamic monetary policies are very supportive of the real sector to be developed. Based on the word of Allah in Surah Al-Baqarah verse 275 which snippet of the verse: "Allah has permitted buying and selling and forbids usury" this interprets that in Islamic Economics the main sector is buying and selling (goods and services) which comes from real sector productivity. And in the Islamic monetary economic policy, the application of interest is not applied, so that the stability of the 
value of money is more guaranteed, this will obviously reduce the spike in inflation, as a result prices remain stable and productivity of the real sector is maintained. 


\section{REFERENCES}

Al., A. et. (2012). Qualitative Research Methodology. Faithful Library.

Arikuntoro, S. (2006). Research Procedure A Practical Approach. Rieneka Cipta.

Ascarya. (2009). Toward Optimum Synergy of Monetary Policy in Dual

Financial/Banking System. Journal of Indonesian Economy and Business, 24(1), 33-48. https://doi.org/10.22146/jieb.6331

Budiono. (2001). Synopsis Series Introduction to Economics N-2. Macroeconomics. BPFE.

Chapra, M. U. (2001). The Future of Economics: An Overview of Islam, Translation of the Ikhwan Abidin Basri. Gema Insani Press.

Karim, A. A. (2001). History of Islamic Economic Thought. IIIT.

Karim, A. A. (2013). Introduction to Islamic Macroeconomics. Salemba Empat.

Muhammad. (n.d.). Contemporary Muslim Financial Institutions. UII Press.

Muhammad. (2002). Fiscal and Monetary Policy in Islam. Salemba Empat.

NabhanI, T. A. (1996). Building an Alternative Economic System with an Islamic Perspective. Risalah Gusti.

Saud, M. A. (1996). Outlines of Islamic Economic. Gema Insani Press.

Setiawan, M. A. (2015). The Role of Real Sector Investment to Improve the Economy in West Sumatra in Facing the ASEAN Economic Community. SNEMA.

Siregar, M. (2001). Alternative Monetary Management. In in Gold Dinar-Monetary Crisis Solutions. Sirac. SEM Institute. Infid.

Sujarweni, V. W. (2014). Research Methodology. New Pustaka Press.

Syauqi, I. (2016). Sharia Development Economics. Raja Grafindo Persada. 